\title{
Partisipasi Masyarakat dalam Musyawarah Perencanaan Pembangunan (MUSRENBANG) Tahun 2019 di Kabupaten Bondowoso Perspektif Undang-Undang Nomor 6 Tahun 2014 tentang Desa
}

\author{
Mohammad Wasil ${ }^{1}$ \\ ${ }^{1}$ Fakultas Syariah, IAIN Jember. E-mail: wasil3658@gmail.com
}

\begin{tabular}{|c|c|}
\hline Article & bstract \\
\hline $\begin{array}{l}\text { How to cite: } \\
\text { Mohammad Wasil, } \\
\text { ‘Partisipasi Masyarakat } \\
\text { dalam Musyawarah } \\
\text { Perencanaan } \\
\text { Pembangunan } \\
\text { (MUSRENBANG) Tahun } \\
2019 \text { di Kabupaten } \\
\text { Bondowoso Perspektif } \\
\text { Undang-Undang Nomor } 6 \\
\text { Tahun 2014 tentang Desa' } \\
\text { Vol. } 1 \text { No. } 1 \\
\text { Rechtenstudent Journal } \\
\text { Fakultas Syariah IAIN } \\
\text { Jember. }\end{array}$ & 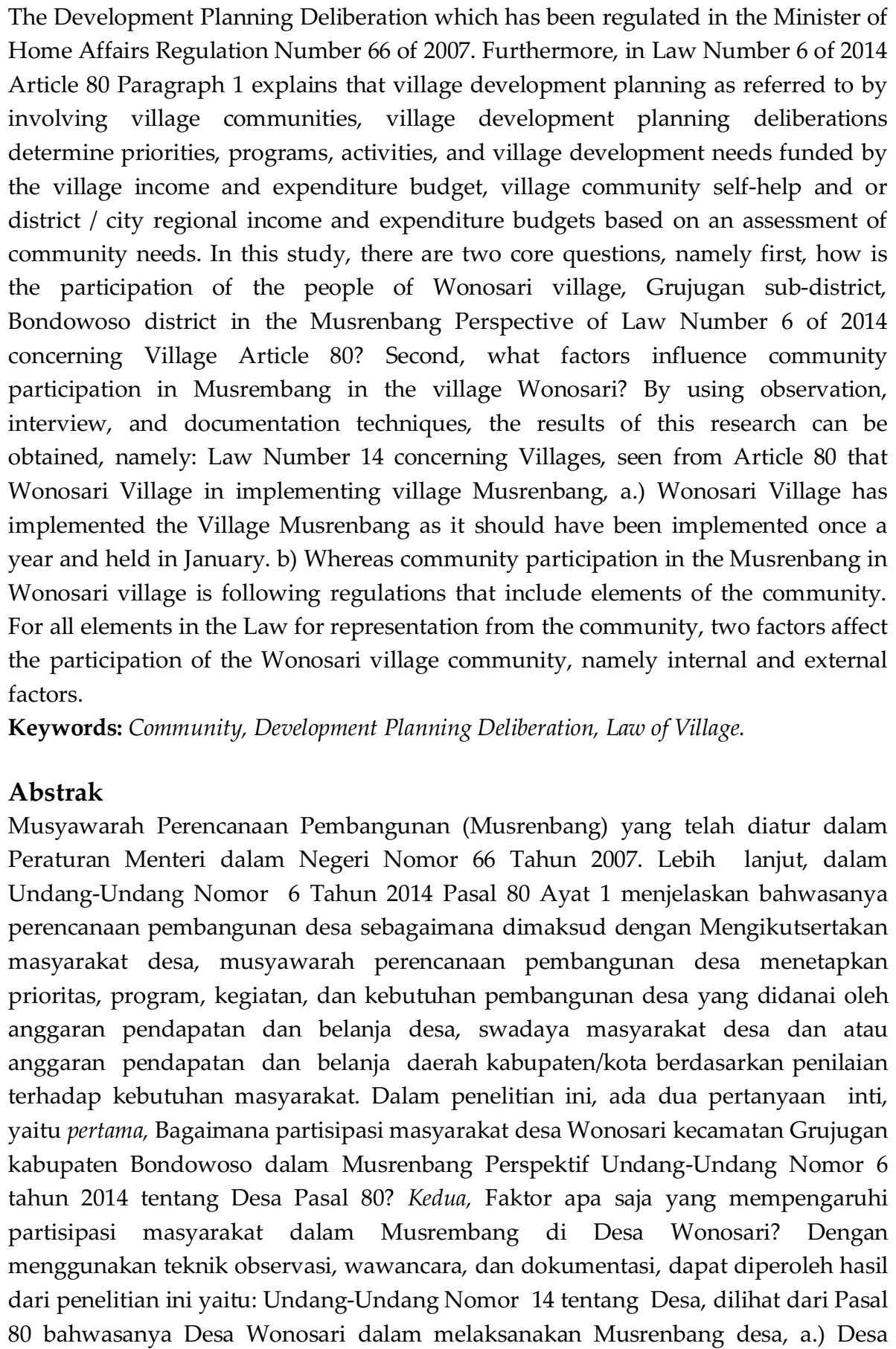 \\
\hline
\end{tabular}


Wonosari telah melaksanakan Musrenbang desa sebagaimana mestinya dilaksanakan satu tahun sekali dan dilaksanakan di bulan Januari. b) Bahwa partisipasi masyarakat dalam Musrenbang di Desa Wonosari sudah sesuai dengan peraturan yang mengikutsertakan unsur masyarakat. Semua unsur di undangundang untuk keterwakilannya dari masyarakat, terdapat dua faktor yang mempengaruhi partisipasi masyarakat Desa Wonosari yakni faktor internal dan eksternal.

Kata Kunci: Masyarakat, Musrenbang, Undang-Undang tentang Desa.

\section{Pendahuluan}

Sejak tahun 1966, Pemerintah Orde baru telah membangun suatu pemerintahan nasional yang kuat dengan menempatkan stabilitas politik sebagai landasan untuk mempercepat pembangunan ekonomi Indonesia. Dalam kerangka struktur sentralisasi kekuasaan politik dan otoritas administrasi inilah Undang-Undang No. 5 Tahun 1974 yang mengatur pokokpokok pemerintahan daerah dibentuk Undang-Undang No. 5 Tahun 1974 ini meletakkan dasar sistem hubungan pusat ke daerah yang dirangkum dalam tiga prinsip, yaitu Desentralisasi, ${ }^{1}$ Dekonsentrasi ${ }^{2}$, dan Tugas Pembantuan. ${ }^{3}$

Pembangunan nasional merupakan rangkaian upaya pembangunan yang berkesinambungan yang meliputi seluruh kehidupan masyarakat berbangsa dan negara. Berdasarkan pokok pikiran di atas maka hakikat pembangunan nasional adalah pembangunan manusia Indonesia seutuhnya dan pembangunan masyarakat Indonesia seluruhnya dengan Pancasila sebagai dasar, tujuan, pedoman pembangunan nasional. Pembangunan nasional dilaksanakan bersama oleh masyarakat dan pemerintah masyarakat adalah pelaku utama pembangunan dan pemerintah berkewajiban untuk mengarahkan, membimbing, serta menciptakan suasana yang menunjang, saling mengisi dan saling melengkapi dalam satu kesatuan menuju tercapainya tujuan pembangunan. ${ }^{4}$

Undang-Undang Nomor 25 Tahun 2004 tentang Sistem Perencanaan Pembangunan Nasional telah menetapkan Rencana Pembangunan Jangka Panjang Nasional yang merupakan penjabaran dari tujuan dibentuknya pemerintahan negara Indonesia. Desa yang memiliki hak asal-usul dan hak tradisional dalam mengatur dan mengurus kepentingan masyarakat berperan mewujudkan cita-cita kemerdekaan berdasarkan Undang-Undang Dasar Negara Republik Indonesia Tahun 1945 perlu dilindungi dan diberdayakan agar menjadi kuat, maju, mandiri, dan demokratis sehingga dapat menciptakan landasan yang

\footnotetext{
1 Desentralisasi adalah penyerahan urusan pemerintahan dari urusan pemerintah daerah tingkat atas kepada daerah menjadi urusan daerah urusan rumah tangganya, Desentralisasi di bidang pemerintahan atau Otonomi adalah penyerahan kewenangan untuk mengatur dan menyelenggarakan pemerintahan kepada daerah, penyerahan ini berarti memberikan kesempatan kepada aparat daerah termasuk wakil-wakil rakyatnya berpartisipasi dalam merencanakan dan melaksanakan berbagai kebijaksanaan pembangunan tanpa harus mendapatkan arahan atau diarahkan oleh pusat (top-down atau bottom up) dan pada akhirnya pemerintah daerah tidak akan terima jadi dari pusat. Pembangunan daerah dengan demikian lebih berorientasi pada kebutuhan setempat (buttom up oriented) yang sesuai dengan kemampuan perencanaan yang disesuaikan dengan kebutuhan bukan didasarkan kepada kemauan yang menjadi landasan pembangunan daerah. Dalam Widjaja Haw, Titik Berat Otonomi Pada Daerah Tingkat II (Jakarta: Raja Grafindo Persada 2001), 61.

${ }^{2}$ Dekonsentrasi adalah pelimpahan wewenang administrasi dari suatu pemerintah pusat kepada pejabat daerah. Pelimpahan wewenang hanya sebagai kewenangan administrasi saja, untuk kewenangan politik tetap di tangan pemerintahan pusat. Jadi Dekonsentrasi bisa dikatakan sebagai kombinasi antara sentralisasi dan desentralisasi. ${ }^{3}$ Mudrajad kuncoro, Otonomi dan Pengembangan Daerah (Jakarta: Erlangga.1988), 78.

${ }^{4}$ Editor, Arnicun Aziz Lima Garis Besar Haluan Negara, (Jakarta: Sinar graika), 11.
} 
kukuh dalam melaksanakan pemerintahan dan pembangunan menuju masyarakat yang adil, makmur, dan sejahtera. Dengan demikian, tujuan ditetapkannya pengaturan desa dalam undang-undang ini merupakan penjabaran lebih lanjut dari ketentuan sebagaimana dimaksud dalam Pasal 18 ayat (7) dan Pasal 18B ayat (2) Undang-Undang Dasar Negara Republik Indonesia Tahun 1945.

Undang-undang ini menggunakan dua pendekatan, yaitu membangun desa yang diintegrasikan dalam perencanaan pembangunan desa. Sebagai konsekuensinya desa menyusun perencanaan pembangunan sesuai dengan kewenangannya dengan mengacu pada perencanaan pembangunan suatu kabupaten/kota. Dokumen rencana pembangunan desa merupakan satu-satunya dokumen perencanaan di desa dan sebagai dasar penyusunan anggaran pendapatan dan belanja desa. Perencanaan pembangunan desa diselenggarakan dengan mengikutsertakan masyarakat desa melalui musyawarah perencanaan pembangunan desa.

Musyawarah Perencanaan Pembangunan (Musrenbang) desa menetapkan prioritas, program, kegiatan, dan kebutuhan pembangunan desa yang didanai oleh anggaran pendapatan dan belanja desa, swadaya masyarakat desa dan atau anggaran pendapatan dan belanja daerah kabupaten/kota berdasarkan penilaian terhadap kebutuhan masyarakat. Pembangunan desa dilaksanakan oleh pemerintah desa dan masyarakat desa dengan semangat gotong royong serta memanfaatkan kearifan lokal dan sumber daya alam desa. Pelaksanaan program sektor yang masuk ke desa diinformasikan kepada pemerintah desa dan diintegrasikan dengan rencana pembangunan desa. Masyarakat desa berhak mendapatkan informasi dan melakukan pemantauan mengenai rencana dan pelaksanaan pembangunan desa. ${ }^{5}$

Musrenbang wajib diselenggarakan, menurut Undang-Undang Republik Indonesia Nomor 6 Tahun 2014 tentang Desa, karena dari hasil kegiatan Musrenbang akan memperoleh informasi (assesmen) paling penting terhadap usulan program yang diprioritaskan dari masyarakat karena apa yang dihasilkan merupakan kebutuhan masyarakat yang sebenarnya. ${ }^{6}$ Sangan di sayangkan Musrenbang seringkali belum mencerminkan semangat musyawarah yang bersifat partisipatif dan dialogis. Musrenbang belum menjadi ajang yang bersahabat bagi warga masyarakat terutama kelompok miskin dalam menyuarakan aspirasi dan kebutuhannya.

Suara kelompok miskin dan perempuan seringkali tersingkir pada saat penetapan prioritas program dan kegiatan pembangunan didaerah. Selanjutnya menarik untuk di teliti tentang suatu Desa Wonosari Kecamatan Grujugan yang terletak di bagian selatan kabupaten Bondowoso yang menurut peneliti masih terdapat beberapa pembangunan yang kurang dari segi infrastruktur seperti jalan di salah satu dusun dan lainya yang masih perlu dilihat bagaimana tingkat penyampaian aspirasi ketika forum itu berlangsung dan menyampaikan ide/gagasan dan beberapa harapan masyarakat setempat, untuk dapat dilakukan perbaikanperbaikan ke depan dan menjadi sekala prioritas, menurut penulis dari tahun ke tahun dalam sebagian wilayah di desa tersebut masih belum ada peningkatan yang signifikan, lalu peneliti ingin menggali apa penyebab dan faktor-faktor dalam perumusan ketika program satu tahun dalam tahap pengkajian bersama.

5Penjelasan atas Undang-Undang Republik Indonesia Nomor 6 tahun 2014 tentang Desa ${ }^{6}$ Undang -Undang RINomor6Tahun2014 Pasal 80tentangDesa. 


\section{Rumusan Masalah}

Adapun rumusan masalah dalam penelitian ini adalah:

1. Bagaimana partisipasi masyarakat desa Wonosari kecamatan Grujugan kabupaten Bondowoso dalam Musrenbang Perspektif Undang-Undang Nomor 6 tahun 2014 tentang Desa?

2. Faktor apa saja yang mempengaruhi partisipasi masyarakat dalam Musrembang di Desa Wonosari?

\section{Partisipasi Masyarakat dalam Pelaksanaan Musyawarah Perencanaan Pembangunan (Musrenbang) Tahun 2019 di Desa Wonosari Kecamatan Grujugan Kabupaten Bondowoso}

Dalam Pasal 18 Undang-Undang Dasar 1945 disebutkan bahwa Negara Kesatuan Republik Indonesia dibagi atas daerah-daerah provinsi dan daerah provinsi itu di bagi atas kabupaten dan kota mempunyai pemerintahan daerah yang di atur dalam undang undang dijelaskan kembali bahwa dalam Bab XIV Kesejahteraan Pasal 33 tercantum dasar demokrasi ekonomi, produksi dikerjakan oleh semua untuk semua di bawah pimpinan atau pemilikan anggota-anggota masyarakat, kemakmuran masyarakatlah yang diutamakan bukan kemakmuran orang perorang. ${ }^{7}$

Hal demikian juga menjadi titik fokus dalam adanya suatu pembangunan partisipatif. Pembangunan partisipatif adalah suatu sistem pengelolaan pembangunan di desa bersamasama secara musyawarah, mufakat, dan gotong-royong yang merupakan cara hidup masyarakat yang telah lama berakar budaya di wilayah Indonesia. Hal demikian diatur dalam Pasal 80 ayat (1) Undang-Undang Republik Indonesia No. 6 Tahun 2014 tentang Desa yang menjelaskan bahwa forum Musrenbang mengharuskan adanya keterlibatan masyarakat dalam perencanaan pembangunan, yang dikenal dengan istilah Forum Musrenbang Desa. Perencanaan Pembangunan Desa sebagaimana dimaksud dalam Pasal 79 "diselenggarakan dengan mengikut sertakan Masyarakat Desa".

Untuk memastikan adanya keterlibatan atau partisipasi masyarakat dalam Musrenbang pada tahun 2019 di Desa Wonosari Kecamatan Grujugan Kabupaten Bondowoso, Peneliti mewawancarai bapak Nurhasan Selaku Sekretaris Desa Wonosari selaku salah satu orang yang terlibat langsung dalam forum Musrenbang tersebut. Terkait dengan jumlah berapa banyak partisipan/undangan yang hadir ketika forum Musrenbang itu di laksanakan. Bahwa dalam pelaksanaan forum tersebut, semua elemen turut andil dan antusias dari masyarakat tersebut sangat tinggi dengan meibatkan semua tokoh, termasuk tokoh agama, pemuda, perempuan, dan lain-lain sesuai dengan perundang undanganan yang ada. Semua partisipan terlibat aktif menyampaikan beberapa usulan terkait dengan usulan dari daerah/dusun dari masing-masing partisipan tersebut. ${ }^{8}$

Peneliti Juga menggali informasi mewawancarai Bapak Sahri selaku Ketua dari Badan Permusyawaratan Desa (BPD) Desa Wonosari Kecamatan Grujugan Kabupaten Bondowoso. Sahri berbendapat dengan adanya kegiatan Musrenbang ini, dari warga desa Wonosari ini partisipasinya cukup banyak setiap ada undangan mayoritas hadir. ${ }^{9}$ Peneliti juga melakukan

\footnotetext{
7Undang-Undang Dasar 1945 Pasal 18

${ }^{8}$ Nur Hasan, Wawancara, Desa Wonosari Kecamatan Grujugan Kabupaten Bondowoso, 6 Januari 2020

9Sahri, Wawancara, Badan Permusyawaratan Desa Wonosari Kecamatan Grujugan Kabupaten Bondowoso, 8 Januari 2020.
} 
wawancara degan salah satu tokoh masyarakat yakni Bapak Untung, selaku tokoh masyarakat di desa Wonosari.

"Forumnya memang sudah di lakukan tiap tahun, dan masyarakat dilibatkan, di dusun ini sekitar 10 orang atau lebih yang di undang dalam forum itu, Terdiri dari RT Rw/Kepala dusun, tokoh agama para pendidik, dan tokoh lainya, diundang dalam forum tersebut, mereka menghadiri menyampaikan semua aspirasi mereka kadang waktupun tidak cukup untuk menampung dan mengizinkan semua berpendapat, hampir semua peserta suka mengusulkan," ${ }^{10}$

Sebagaimana disebutkan dalam Pasal 80 ayat 2 bahwa, dalam menyusun perencanaan pembangunan desa sebagaimana dimaksud pada ayat (1), pemerintah desa wajib menyelenggarakan musyawarah perencanaan pembangunan desa artinya dalam menyusun perencanaan pembangunan desa, pemerintah desa wajib hukumnya menyelenggarakan Musyawarah Perencanaan Pembangunan Desa. Untuk menjawab Pasal 2 ini,peneliti melakukan wawancara lebih mendalam yang sesuai kepada sekretaris desa Bapak Nur Hasan mengenai apakah Musrenbang sudah selenggarakan untuk tahun 2019

“Apa yang diperintahkan Undang-Undang sudah kami selenggarakan dan kami realisasikan karena merupakan suatu keharusan atau kewajiban untuk kita jalankan, Kami menyelenggarakan Musrenbang itu di bulan Januari mas, Ya Alhamdulillah terselenggara dengan lancar."11

Berdasarkan informasi tersebut bahwa desa Wonosari menjalankan amanat UndangUndang Pasal 80 ayat 2 Tersebut sudah diselenggarakan dengan bukti dokumentasi dan daftar hadir dalam acara Musrenbang dan dari ketiga informan menjelaskan adanya Musrenbang dan pelaksanaannya.

Sebagaimana yang tertuang dalam aturan Pasal 80 ayat 3 bahwa musyawarah perencanaan pembangunan desa menetapkan prioritas, program, kegiatan, dan kebutuhan pembangunan desa. Dalam penggalian data yang telah dilakukan, bahwa Musrembang dilakukan dengan membahas menyepakati usulan, seperti saluran irigasi, jalan, paving dan beberapa penetapan prioritas untuk dapat dibangun dan dikembangkan dengan menyusun anggaran dalam satu tahun mendatang. ${ }^{12}$ Dikuatkan dengan pernyataan Bapak Sahri bahwa yang menjadi prioritas utama dalam pembahasan Musrembang yaitu seperti bangunan pelengsengan pinggir saluran air ke sawah-sawah orang, terutama jalan-jalan desa dan lainya. ${ }^{13}$

Dalam Pasal 80 ayat 4, menyebutkan kegiatan dan kebutuhan pembangunan desa peningkatan kualitas dan akses terhadap pelayanan dasar, pembangunan dan pemeliharaan infrastruktur dan lingkungan berdasarkan kemampuan teknis dan sumber daya lokal yang tersedia, pengembangan ekonomi pertanian berskala produktif, pengembangan dan pemanfaatan teknologi tepat guna untuk kemajuan ekonomi, peningkatan kualitas ketertiban dan ketenteraman masyarakat Desa.

Berdasarkan kebutuhan pelayanan dasar dari pemerintah desa kepada masyarakat di desa Wonosari ini, Peneliti mewawancarai lagi kepada bapak sekretaris desa yakni bapak Nur

\footnotetext{
${ }^{10}$ Untung, Wawancara, Tokoh Masyarakat Dusun Curahlempet Desa Wonosari Kecamatan Grujugan Kabupaten Bondowoso, 12 Januari 2020.

${ }^{11}$ Nur Hasan, Wawancara, Desa Wonosari Kecamatan Grujugan Kabupaten Bondowoso, 6 Januari 2020.

${ }^{12}$ Nur Hasan, Wawancara, Desa Wonosari Kecamatan Grujugan Kabupaten Bondowoso, 6 Januari 2020.

${ }^{13}$ Sahri, Wawancara, Badan Permusyawaratan Desa Wonosari Kecamatan Grujugan Kabupaten Bondowoso, 8 Januari 2020.
} 
Hasan berkenaan dengan dirumuskannya kebijakan pemanfaatan lingkungan dan sumberdaya lokal berdasarkan penilaian terhadap kebutuhan masyarakat Desa Wonosari ini dari beberapa usulan untuk pengembangan desa tersebut. Diperkuat dengan data yang diperoleh dengan bertanya kepada bapak Ketua BPD bapak Sahri selaku pihak terkait berkenaan dengan dirumuskannya berdasarkan penilaian terhadap pemanfaatan sumber daya lokal hal yang mendasar bagi masyarakat. Bahwa dalam kriteria penilaian, tidak serta merta semua usulan disetujui, namun dipertimbangkan terlebih dahulu untuk ditetapkan. Jadi, dapat dilihat mana yang lebih membutuhkan. Masyarakat juga mengandalkan sumber daya lokal yaitu sumber daya manusia untuk merawat infrastruktur yang sudah ada. ${ }^{14}$

Dengan data yang diperoleh dari tiga informan sebagaimana peneliti lakukan dan menganalisa berdasarkan data-data yang diterima, bahwa peneliti menganalisa di desa Wonosari antara Das Sollen dan Dassein tersebut dalam pelaksanaan Musrenbang desa tahun 2019.

\section{Faktor-faktor yang Mempengaruhi Partisipasi Masyarakat}

Berbicara tentang partisipasi masyarakat dalam pembangunan sejalan dengan luasnya lingkup konsep tersebut dalam wacana pembangunan, ada beberapa faktor Faktor yang memperingati yang menyangkut partisipasi masyarakat dalam perencanaan pembangunan. Beberapa kebutuhan tentunya juga masih diperlukan di desa Wonosari tersebut. Di antaranya yaitu kebutuhan yang ada pembangunan secara fisik dan non fisik, juga ada perwakilan dari dusun per dusun dari unsur itu sudah mengusulkan bangunan yang disesuaikan dengan kebutuhannya. ${ }^{15}$

Peneliti melihat dari struktur pemerintahan di situ ada konsep pelimpahan wewenang pada kepala dusun bagian dari struktural yang ada di Desa Wonosari Kecamatan Grujugan Kabupaten Bondowoso tersebut. Dalam pra-Musrenbang desa adanya undangan tersebut kepada beberapa elemen dalam masyarakat di setiap dusun tersebut untuk dapat disalurkannya aspirasi warga Desa Wonosari di dalam pelaksanaan Musrenbang itu. Diperjelas juga bahwa partisipasi masyarakat dipengaruhi oleh dua faktor yaitu internal dan eksternal.

\section{a. Faktor internal}

Faktor internal yaitu mencakup karakteristik individu yang dapat mempengaruhi individu tersebut untuk berpartisipasi dalam suatu kegiatan, yaitu umur, jenis kelamin, status dalam keluarga, tingkat pendidikan, etnis, agama, bahasa, pekerjaan, tingkat pendapatan, jarak rumah dengan lokasi pekerjaan atau aktivitas dan kepemilikan tanah (Cohen, J. and Uphoff, 1977)

Untuk menelaah lebih jauh mengenai faktor yang pertama dapat mempengaruhi tingkat partisipasi masyarakat dalam Musrenbang Desa Wonosari ini sesuai dengan yang dinyatakan dalam teorinya Cohen, J. and Uphoff. Peneliti melakukan wawancara kepada bapak Nur Hasan.

"Begini ya mas, memang yang kita undang untuk mengikuti Musrenbang ini kebanyakan adalah tokoh, ya dari berbagai golongan sekitar umur dari 18 sampai 40-

\footnotetext{
${ }^{14}$ Sahri, Wawancara, Badan Permusyawaratan Desa Wonosari Kecamatan Grujugan Kabupaten Bondowoso, 8 Januari 2020.

${ }^{15}$ Sahri, Wawancara, Badan Permusyawaratan Desa Wonosari Kecamatan Grujugan Kabupaten Bondowoso, 8 Januari 2020.
} 
anlah yang ikut terlibat dalam forum Musrenbang ini, dan kebanyakan laki laki, dan berbagai macam latar belakang ada yang belum menikah ada yang sudah berkelurga dan memiliki anak, dan pendidikanya cukup berfariasi dik, dan rata rata ya lebih banyak petani, karena memang mayoritas masyarakat Wonosari adalah petani dan buruh tani, meskipun latar belakang seperti itu namun antusias dari warga masyarakat desa Wonosari ini cukup tinggi mas karena sadar akan pembangunan desa". ${ }^{16}$

Untuk Memperkuat data peneliti ini juga menanyakan kepada Bapak Sahri selaku Ketua Badan permusyawaratan desa mengenai faktor yang yang mempengaruhi tingkat partisipasi masyarakat dalam Musrenbang desa Wonosari ini sesuai dengan yang dinyatakan dalam Teorinya Cohen, J. and Uphoff Bahwasanya bapak Sahri dalam pendapatnya

"Bahwasanya pelaksanaan ini dik di ikuti lebih banyak oleh para laki laki, bukan dari kalangan perempuan tidak ada, ada, hanya sebagian saja akan tetapi masih lebih banyak laki-laki yang mengikuti Musrenbang ini, umurnya dari yang muda juga ada yang bapak bapak juga lebih banyak, disini banyak yang petani hampir semua petani, pendidikanya ada lulusan SD, SMP, SMA, dan, ya macam macamlah dik" ${ }^{17}$

Musrenbang kebanyakan diikuti oleh tokoh dari berbagai golongan berkisar umur dari 18 sampai 40 tahunan yang ikut terlibat aktif dalam forum Musrenbang tersebut, dan kebanyakan laki laki dari peserta forum tersebut, dan berbagai macam latar, ada yang belum menikah, ada yang sudah berkeluarga dan memiliki anak, latar pendidikanya dari peserta Musrenbang tersebut cukup bervariasi dan kebanyakan dari petani, karena memang mayoritas masyarakat Wonosari adalah petani dan buruh tani, meski latar belakang seperti itu namun antusias dari warga masyarakat desa Wonosari ini cukup tinggi mas karena sadar akan pembangunan desa.

\section{b. Faktor eksternal}

Faktor eksternal adalah semua pihak luar yang berkepentingan dan mempunyai pengaruh terhadap program tersebut, antara lain pengurus desa, tokoh masyarakat, Pemerintah Daerah, NGO, pihak ketiga (LSM, Yayasan Sosial, Perguruan Tinggi). Hal yang penting adalah adanya pengaruh bagaimana peran peran dari stakeholder yang cukup menunjang bagi masyarakat setempat dalam meningkatkan daya partisipasi yang cukup tinggi, peran ini sangat berpengaruh dalam suatu kelompok bagaimana menciptakan kesadaran dalam berkehidupan, prihatin akan suatu daerah dan cinta terhadap pembangunan kerjasama dalam jangka waktu yang cukup lama.

Untuk menggali informasi peneliti melakukan wawancara kepada bapak Nur Hasan sekretaris Desa Wonosari guna menggali informasi.

"Kami selaku perangkat desa sudah menjadi kewajiban dan tanggung jawab kami dalam melaksanakan Musrenbang desa ini, yang kami undang adalah tokoh tokoh yang cukup berpengaruh di lingkungan masyarakat sekitarnya, berbagai upaya telah kami lakukan agar masyarakat tetap ikut andil dalam musyawarah dan berbagai

\footnotetext{
${ }^{16}$ Nur Hasan, Wawancara, Desa Wonosari Kecamatan Grujugan Kabupaten Bondowoso, 6 Januari 2020

${ }^{17}$ Sahri, Wawancara, Badan Permusyawaratan Desa Wonosari Kecamatan Grujugan Kabupaten Bondowoso, 8 Januari 2020
} 
kegiatan lain yang kami laksanakankan mas, untuk itu saya kira khususnya pemerintahan Desa Wonosari melakukan apa yang menjadi tugas kami". ${ }^{18}$

Tentu untuk memperkuat data yang kami peroleh peneliti juga memperdalam dengan menggali data dari bapak sahri selaku ketua BPD desa Wonosari Kecamatan Grujugan Kabupaten Bondowoso.

"Kalau Terkait dengan itu perangkat desa ya menurut saya sudah menjalankan apa yang semestinya, buktinya ketika Musrenbang dan acara rembuk desa lainya masyarakat selalu di undang dan hadir di sebuah acara tersebut, peran tokoh lainya sangat berpengaruh juga seperti kepala dusun, tokoh masyarakat dan terutama kiai/ustadz, namun tokoh tersebut juga di undang sehingga partisipasi menurut saya cukup tunggu". ${ }^{19}$

Peneliti menganalisis bahwa perangkat desa sudah menjadi tugasnya, salah satunya dengan mengadakan Musrenbang desa para tokoh-tokoh yang cukup berpengaruh di lingkungan masyarakat sekitarnya kami undang. Alhasil mereka banyak yang hadir bukti bahwa pengaruh perangkat desa cukup tinggi, berbagai upaya telah di lakukan oleh pemerintah desa Wonosari agar masyarakat tetap ikut andil dalam musyawarah dan berbagai kegiatan lain yang dilaksanakan. Peneliti menemukan bahwa dalam Musrenbang tersebut masyarakat hanya menyampaikan kebutuhan untuk lingkungan pembangunan infrastruktur, dan menyampaikan seluruh usulannya, Penetapan hasil Musrenbang tersebut di tetapkan oleh pemerintah desa beserta Badan Permusyawaratan Desa (BPD).

\section{Kesimpulan}

Di dalam Undang-Undang Nomor 14 tentang Desa, dilihat dari Pasal 80 bahwasanya Desa Wonosari dalam melaksanakan Musrenbang desa tersebut telah dilakukan sebagaimana mestinya, yaitu pada satu tahun sekali dan dilaksanakan di bulan Januari. Bahwa partisipasi masyarakat dalam Musrenbang di desa Wonosari sudah sesuai dengan peraturan sudah mengikutsertakan usur atau semua elemen masyarakat. Dalam Musrenbang Desa tersebut terdapat usulan oleh masyarakat setempat, seperti perengsengan, jalan, dan paving belum sepenuhnya terealisasikan di setiap dusunnya, masih dalam tahapan dari satu dusun ke dusun lainya. Adapun faktor yang mempengaruhi partisipasi masyarakat yaitu adanya dua faktor. Dari faktor internal dapat disimpulkan bahwa kesadaran masyarakat Wonosari cukup tinggi, dilihat dari latar belakang pendidikan yang tergolong masih minim lulusan sarjana namun kesadaran dan partisipasi cukup tinggi dilihat dari jumlah undangan dan yang hadir dalam Musrenbang tersebut. Serta faktor eksternal yang juga memiliki pengaruh cukup besar dalam terselenggaranya Musrenbang Desa Wonosari pada tahun 2019, begitupun juga peran penting tokoh masyarakat sekitar dalam pelaksanaan tersebut sangat mempengaruhi jalanya pemerintahan desa Wonosari bagi masyarakat tokoh agama cukup menjadi panutan.

\section{Daftar Pustaka}

\section{Buku}

Editor, Arnicun Aziz. t.t. Lima Garis Besar Haluan Negara. (Jakarta: Sinar graika).

\footnotetext{
${ }^{18}$ Nur Hasan, Wawancara, Desa Wonosari Kecamatan Grujugan Kabupaten Bondowoso, 6 Januari 2020

${ }^{19}$ Sahri, Wawancara, Badan Permusyawaratan Desa Wonosari Kecamatan Grujugan Kabupaten Bondowoso, 8 Januari 2020.
} 
Hasan,Nur.Wawancara, Desa Wonosari Kecamatan Grujugan Kabupaten Bondowoso, 6 Januari 2020.

Haw, Widjaja. 2001. Titik Berat Otonomi Pada Daerah Tingkat II. (Jakarta: Raja Grafindo Persada) Kuncoro, Mudrajad. 1988. Otonomi dan Pengembangan Daerah. (Jakarta: Erlangga).

\section{Perundang-undangan}

Undang-Undang Republik Indonesia Nomor 6 Tahun 2014 tentang Desa.

Undang-Undang Dasar 1945.

\section{Wawancara}

Untung. Wawancara, Tokoh Masyarakat Dusun Curahlempet Desa Wonosari Kecamatan Grujugan Kabupaten Bondowoso, 12 Januari 2020.

Sahri. Wawancara, Badan Permusyawaratan Desa Wonosari Kecamatan Grujugan Kabupaten Bondowoso, 8 Januari 2020. 